ALVAREZ, JM; PASIAN, C; LAL, R; LÓPEZ, R; FERNÁNDEZ, M. 2019. Vermicompost and biochar substrates can reduce nutrients leachates on containerized ornamental plant production. Horticultura Brasileira 37: 047-053. DOI - http://dx.doi.org/10.1590/S0102-053620190107

\title{
Vermicompost and biochar substrates can reduce nutrients leachates on containerized ornamental plant production
}

\author{
José M Alvarez ${ }^{1,2} \mathbb{D}$; Claudio Pasian ${ }^{2} \mathbb{D}$; Rattan Lal ${ }^{2} \mathbb{D}$; Rafael López ${ }^{3 \mathbb{D}}$; Manuel Fernández ${ }^{1 \mathbb{D}}$ \\ ${ }^{1}$ Escuela Técnica Superior de Ingeniería, Universidad de Huelva, Huelva, Spain; josemaria.alvarez254@alu.uhu.es (corresponding author);

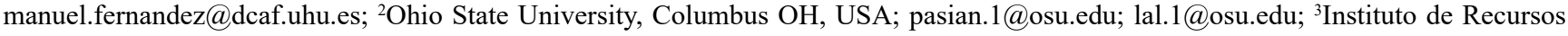 \\ Naturales y Agrobiología de Sevilla, Consejo Superior de Investigaciones Científicas, Sevilla, Spain; rlnunez@irnase.csic.es
}

\begin{abstract}
Containerized ornamental plant production is facing several environmental challenges. One of them is to replace the widely used, but with questionable sustainability, peat based substrates and another is to avoid water contamination by chemicals leaching from the nursery. Therefore, as have been verified that petunia and pelargonium plants can be produced in peat-based growing media partially replaced by vermicompost $(V)$ and biochar $(B)$ without decreasing commercial quality, this study has focused on analyzing the leachate from a standard peat-based substrate as a control, used for producing these two ornamental species, and those from the same substrate to which different proportions in volume of $V(10 \%$ and $20 \%)$ and $B(4 \%$ and $12 \%)$ have been added. The amount of nitrogen leached from the mixed substrates was reduced compared to the control one in both species (on average 37\%). Nitrogen was leached mainly as nitrate-nitrogen ( $89 \%$ in Petunia and $97 \%$ in Pelargonium). In Petunia phosphorous leaching was also decreased (30\%) for the treatment with $10 \% \mathrm{~V}$ and $4 \% \mathrm{~B}$, while potassium leaching in substrate containing $20 \% \mathrm{~V}$ and $12 \% \mathrm{~B}$ increased by $100 \%$. Our results show that these two organic materials tested $(V$ and $B)$ can help producers to reduce the use of peat and chemical fertilizers as well as the risk of contamination by chemicals, mainly nitrate.
\end{abstract}

Keywords: Petunia hybrida, Pelargonium peltatum, peat replacement, water contamination, nitrate, phosphate.

\section{RESUMO}

Substratos de vermicomposto e biochar podem reduzir os lixiviados de nutrientes na produção de plantas ornamentais em contêineres

A produção de plantas ornamentais em contêineres está enfrentando vários desafios ambientais. Um deles é substituir os substratos amplamente utilizados, mas com sustentabilidade questionável, baseados em turfa, e outro é evitar a contaminação da água por produtos químicos lixiviados do viveiro. Verificou-se que as plantas de petúnia e gerânio podem ser produzidas em meios de crescimento baseados em turfa parcialmente substituídos por vermicomposto $(V)$ e biochar $(B)$ sem diminuir a sua qualidade comercial. Este estudo concentrou-se na análise do lixiviado de uma turfa padrão como controle, utilizado para a produção destas duas espécies ornamentais, e o mesmo substrato ao qual foram adicionados diferentes proporções em volume de $V(10 \%$ e $20 \%)$ e $B(4 \%$ e $12 \%)$. Verificou-se que a quantidade de nitrogenio lixiviado dos substratos misturados foi reduzida em comparação com a testemunha em ambas as espécies (em média 37\%). O nitrogênio foi lixiviado principalmente como nitrato-nitrogênio (89\% em Petunia e $97 \%$ em Pelargonium). Na Petunia a lixiviação de fósforo também foi reduzida (30\%) para o tratamento com $10 \%$ de $V$ e $4 \%$ de $B$, enquanto a lixiviação de potássio em substrato contendo $20 \%$ de $V$ e $12 \%$ de $B$ aumentou em $100 \%$. Nossos resultados mostram que esses dois materiais orgânicos testados $(V$ e $B)$ podem ajudar os produtores a reduzir o uso de turfa e fertilizantes químicos, bem como diminuir o risco de contaminação por substâncias químicas, principalmente nitrato.

Palavras-chave: Petunia hybrida, Pelargonium peltatum, substituição de turfa, contaminação da água, nitrato, fosfato.

\section{Received on March 22, 2018; accepted on November 16, 2018}

$\mathrm{C}$ ontainerized ornamental plants production has increased all over the world (AIPH, 2017). Growers have to face several environmental challenges both to compile legal requirements and the increasing environmental demands of their customers. We can mention three obstacles on which the producer will have sooner or later to make decisions about.
First, the use of peat as growing media is increasingly weighed. Around 10 to 11 million $\mathrm{kg}$ of this material are used annually in the world for horticultural production (US, 2016). Since peat is considered a non-renewable resource and its use is questioned by the drainage of peatlands (Keddy, 2010). In the frame of the circular economy there is a growing demand to use renewable materials, mainly from the recycling of organic wastes and by-products. Vermicompost $(V)$ and biochar $(B)$ are good candidates to substitute peat as growing media, since it has been proven that, used in the right proportions, they do not reduce, even can improve, the commercial quality of the produced plants (Alvarez et al., 2017, 2018). Vermicompost is a product derived from 
the accelerated biological degradation of organic wastes by earthworms and microorganisms. Biochar is a byproduct of the $\mathrm{C}$-negative pyrolysis technology for bio-energy production from organic materials.

Second, there is increasing awareness of the need to mitigate the effects of climate change. The use of recycled materials and alternative energies to fossil fuels are often the main changes that the ornamental plant production industry introduces when it decides to study and maintain a strategy to track the carbon footprint of its products (Barrett et al., 2016).

Finally, due to the peculiarities of this type of containerized ornamental plants production (Ruter, 1993), irrigation and fertilization management should be adequate to avoid nutrients leaching to public waters adjacent to the area of the production facilities and their eventual contamination (Cabrera, 1997, Majsztrik et al., 2011). Actually, in Europe and the United States there is an increasing pressure to reduce the leachates of horticultural crops for environmental reasons (Guimera et al., 1995). Nitrate, ammonium and phosphates are the ions considered the most problematic irrigation leachates (Mueller et al., 1995) due to their effect in surface waters and impact in public health (Agegnehu et al., 2017).

Our hypothesis is that the inclusion of these two new materials, biochar and vermicompost, in the peat based growing media could reduce the leaching of nutrients while maintaining an adequate plant quality.

Manuscript main objective: in this study the leaching of nitrogen and other nutrients from peat based blends including biochar and vermicompost was assessed in comparison with usual fertilized peat substrates.

\section{MATERIAL AND METHODS}

\section{Plant material and experimental design}

Two ornamental species very much worldwide used were utilized, Petunia $x$ hybrida cv. Dreams Neon and Pelargonium peltatum cv. Summer
Showers. These species were also chosen for their different nutrients needs and rusticity as well as on their salt tolerance, being Petunia more tolerant than Pelargonium (Monk \& Wiebe, 1961; Do \& Scherer, 2013), since vermicompost $(V)$ and biochar $(B)$ could modify mineral nutrients availability, electrical conductivity and $\mathrm{pH}$ (Alvarez et al., 2017).

Commercial products available in the market were used to make up the growing media, biochar $(B)$, vermicompost $(V)$ and a peat-based substrate $(S)$. The biochar is called Soil Reef Pure 02 (Biochar Solutions Inc., Co, USA) and was produced by high temperature pyrolysis, 600 to $800^{\circ} \mathrm{C}$, of Pinus monticola wood. The vermicompost is named Black Diamond Vermicompost (Black Diamond Vermicompost, Ca, USA) and was produced by pre-composting for two weeks the solid fraction of bovine manure using an aerated composting system, then submitted to a vermicompost process for a period of 70 to 80 days. These two renewable organic materials ( $B$ and $V$ ) were used to partially replace a peat-based control substrate $(S)$ called Farfard 3B mixture (SunGro Horticulture Distribution Inc., USA). This peat-based substrate is composed by Canadian Sphagnum peat moss, pine bark, perlite, vermiculite, dolomitic limestone, and a wetting agent, at 6:4:2:1 Peat:Bark:Perlite:Vermiculite volume ratio. Farfard $3 \mathrm{~B}$ received a slow release fertilizer (Scotts Osmocote Plus 15-9-12, 5-6 months release at $21^{\circ} \mathrm{C}$, at a dosage of $5.9 \mathrm{~g} \mathrm{~L}^{-1}$ ). An overview of the main characteristics of these components, and more details appear in table 1 at Alvarez et al. (2017).

Three growing media (mixes) were prepared with the following volume fractions $(S: V: B): 100: 00: 00,86: 10: 04$ and $68: 20: 12$, being, respectively, the control treatment and two treatments containing a slight and a moderate peatbased substrate replacement. The last two treatments were selected based on a previous study when 23 different mixes were compared with $S$ (i.e. $S=100: 00: 00$ treatment), and according to the good plant growth and flowering obtained (Alvarez et al., 2017). Then, bulk density $(D b)$, water holding capacity $(W H C)$, total porosity $(P t)$ and air space $(A s)$ were determined at the beginning of the experiment following the procedures for determining physical properties of horticultural substrates using the NCSU porometer (Fonteno \& Bilderback, 1993). Soluble nutrients, $\mathrm{pH}$ and electric conductivity (EC) were determined in aqueous extracts (1:6 volume fraction) taken from fresh mixtures samples in advance of plants cultivation: nitrate and ammonium by spectrophotometry in a flow autoanalyser (AA III, Bran + Luebbe, Norderstedt, Germany) (Ansorena Miner, 1994); potassium, sulfate and phosphate by ICP-OES (Dahlquist \& Knoll, 1978); EC and pH by a pH-meter/conductimeter (Acumet ${ }^{\mathbb{B}}$ Ap85, USA) (Ansorena Miner, 1994).

Petunia and Pelargonium seeds were germinated in 100 plug trays $\left(21.8 \mathrm{~cm}^{3} /\right.$ cell) and two seeds were added per cell. After germination, just one seedling was kept. Trays were placed in a glasshouse for 40 days at $24^{\circ} \mathrm{C}$ and $54 \%$ average temperature and relative humidity, respectively under a climate control system in the greenhouse. Watering was done with an automatic micro sprinkler irrigation system between dawn and dusk. Nozzles were irrigating at 1.8 $\mathrm{L} / \mathrm{h}$ during 15 seconds every $20 \mathrm{~min}$, with 2 meter diameter and 1 meter overlap. After that, thirty seedlings were randomly obtained, transplanted into $800 \mathrm{~cm}^{3}$ plastic containers and moved to a glass covered greenhouse (average temperature $20^{\circ} \mathrm{C}$ and average humidity $29 \%$ also under a climate control system in the glasshouse) for 68 days until the market size was reached. Standard propagation protocols for these species were followed. The experimental design was a completely randomized design with two replicas. Each replica consisted of 5 plants per species and treatment randomly distributed (5 plants x 3 treatments $\times 2$ species $=30$ plants per replica). The two replicas were placed on separate benches ( 2 replicas x 15 plants $=60$ plants). Plants were rotated periodically to minimize variation in microclimatic conditions. Containers were watered manually as needed with distilled water. The water was added to each pot gradually by using 
a slight volume every time $\left(\leq 10 \mathrm{~cm}^{3}\right)$ and waiting for a few minutes before adding next volume. As soon as a water droplet appeared at the bottom of the pot no more water was added. These few water droplets leached from each pot were taken back to the pot. Therefore, water was gradually added trying to avoid leaching and to keep substrate to field capacity.

\section{Plant growth, leaching parameters and data analysis}

The parameters evaluated were shoot dry weight (SDW) of plants, and containers leachates volume and nutrient contents. At the end of the growing period and before measuring shoot dry weight (SDW) of plants, containers leachates were collected during five consecutive days after receiving a daily watering of $200 \mathrm{~cm}^{3}$. In order to collect the leachate, both a plastic mesh and a plastic cuvette were placed under each container. For every sampling date, the substrate was moistened to field capacity, as described before, one day before collection of the samples. Collected volume was measured and a sample was taken for subsequent nutrient analysis of nitrate-

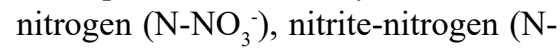
$\left.\mathrm{NO}_{2}^{-}\right)$, ammonium-nitrogen $\left(\mathrm{N}^{-} \mathrm{NH}_{4}^{+}\right)$,

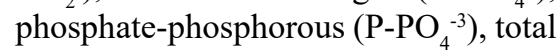
$\mathrm{P}$, sulfate $\left(\mathrm{SO}_{4}^{-2}\right)$. The total nitrogen was calculated as the sum of nitrate-, nitrite-, and ammonium-nitrogen. The nutrient contents (mg) collected in the leachates were calculated by multiplying the concentration $\left(\mathrm{mg} \mathrm{L}^{-1}\right)$ by the collected volume (L). Nutrient analysis was performed by means of standard methods using a multiparameter photometer (HI 83200, Hanna Instruments ${ }^{\circledR}$, Italy).

At the end of the growth period

Table 1. Physical properties, mean (SE), of growth media (treatments) used in the experiment. Columbus, OSU, 2016.

\begin{tabular}{lcccc}
\hline S:V:B & $\mathbf{D b}\left(\mathbf{k g ~ d m}^{-3}\right)$ & $\mathbf{W H C ~ ( \% )}$ & $\mathbf{P t}(\% \mathbf{v} / \mathbf{v})$ & $\mathbf{A s}(\% \mathbf{v} / \mathbf{v})$ \\
\hline $100: 00: 00$ & $0.140(0.03) \mathrm{a}$ & $70.1(0.6) \mathrm{a}$ & $80.1(0.2) \mathrm{a}$ & $10.3(0.9) \mathrm{a}$ \\
$86: 10: 04$ & $0.143(0.05) \mathrm{a}$ & $71.5(0.7) \mathrm{a}$ & $80.3(0.6) \mathrm{a}$ & $8.7(1.2) \mathrm{a}$ \\
$68: 20: 12$ & $0.154(0.02) \mathrm{b}$ & $72.2(0.6) \mathrm{a}$ & $80.7(0.8) \mathrm{a}$ & $8.2(0.3) \mathrm{a}$ \\
\hline$p$ & 0.02 & 0.12 & 0.87 & 0.30 \\
\hline
\end{tabular}

$\mathrm{Db}=$ bulk density $; \mathrm{WHC}=$ water holding capacity $\mathrm{Pt}=$ total porosity; $\mathrm{As}=$ air space $\mathrm{S}=$ peatbased substrate; $\mathrm{V}=$ vermicompost; $\mathrm{B}=$ biochar; Control = 100:00:00. Volume fraction (\%). $\mathrm{p}=$ significance level. Different letters in numerical columns differ at $\mathrm{p} \leq 0.05$ (Tukey-HSD test for Va, Pt and As; T3-Dunnett test for Db).
(100 to $140 \mathrm{~kg} \mathrm{~m}^{-3}$ ), except for control. All the above met the recommendations made by Bilderback et al. (2005) and Yeager (1997).

Figure 1 shows accumulated plants biomass and number of flowers per plant for the two ornamental species grown in the three different treatments. Petunia's SDW and flowering were significantly higher in mixture 86:10:04 compared with control. Treatment 86:10:04 growed up to $37 \%$ and produced $43 \%$ more flowers than the standard peat based substrate. Mix 68:20:12 produced $30 \%$ more flowers than control. In the case of Pelargonium, SDW was similar in all treatments, but flowering in mix 86:10:04 significantly and positively differed from the control, producing up to $108 \%$ more flowers.

In regard to physical and physicochemical characteristics of these three substrates, only bulk density $\left(D_{b}\right)$ was affected by the addition of $V$ and $B$, being the heaviest mixture $(68: 20: 12)$ only a $10 \%$ heavier than the control one. The addition of $V$ to peat substrates usually increase $D_{b}$ (Mupondi et al., 2014; Álvarez et al., 2017), but in this study, taking into account the proportions of $V$ used, it does not seem to have negatively affected the plant growth and nursery management. In respect of plant growth and flower production, our results clearly showed that Petunia and Pelargonium growth and flowering status was enhanced with the inclusion of $B$ and $V$ in peat based substrate in slight or moderate proportions. These results are aligned with other species (Graber et al., 2010; Tian et al., 2012; Mulcahy et al., 2013). For instance, Graber et al. (2010) found an increase in pepper canopy dry weight and flowering by the addition of biochar to a coconut fiber:tuff mix; Tian et al. (2012) obtained similar results growing Calathea rotundifolia plants in 50\% green waste pyrolyzed biochar added to a peat medium, compared to $100 \%$ peat; and an improvement in tomato plant height in growing medium amended with wood pyrolyzed biochar (1 to $5 \%$, weight fraction).

\section{Leachate properties}

On average, Pelargonium 's leachate volume per pot and date $\left(50.6 \mathrm{~cm}^{3}\right)$ was 
47\% lower than Petunia's $\left(74.4 \mathrm{~cm}^{3}\right)$. For both species, neither the effect of treatment $(p \geq 0.107)$ nor treatment $\mathrm{x}$ date interaction $(p \geq 0.561)$ were significant (Figure 2). However, the sampling date was significant $(p \leq 0.005)$ : for Pelargonium it ranged from $33.9 \mathrm{~cm}^{3}$ (day 3) to $68.4 \mathrm{~cm}^{3}$ (day 1), whereas for Petunia it did from $40.5 \mathrm{~cm}^{3}$ (day 1) to $107.7 \mathrm{~cm}^{3}$ (day 5), but without following a defined pattern between consecutive days.

For both species, collected leachates did not show significant differences in $\mathrm{pH}$ between sampling dates $(p \geq 0.165)$ nor for treatment $\mathrm{x}$ date interaction ( $p \geq 0.405$ ), but the effect of treatment was significant $(p<0.001)$. The ranking between treatments was 100:00:00< 86:10:04<68:20:12, with values around neutral, slightly lower for Pelargonium $(6.5<7.1<7.5$, respectively) than for Petunia $(7.0<7.6<7.9$, respectively $)$. The increase in $\mathrm{pH}$ was well correlated to both components added to peatbased substrate. In Petunia, $\mathrm{pH}$ was significantly related to $B\left(R^{2}=0.72\right.$, $p<0.01, \mathrm{n}=30)$ and to $V\left(R^{2}=0.79\right.$, $p<0.01, \mathrm{n}=30)$. Also in Pelargonium, $\mathrm{pH}$ was related to $B\left(R^{2}=0.72, p<0.01\right.$, $\mathrm{n}=30)$ and $V\left(R^{2}=0.69, p<0.01, \mathrm{n}=30\right)$.

EC was higher in Pelargonium $\left(4.3 \pm 0.2 \mathrm{dS} \mathrm{m}^{-1}\right)$ than in Petunia $(1.9 \pm 0.1$ $\left.\mathrm{dS} \mathrm{m}^{-1}\right)$, with no significant differences between sampling dates $(p \geq 0.155)$ nor between treatments for Pelargonium ( $p=$ $0.415)$. However, the treatment effect was significant for Petunia ( $p=0.012)$. The mean values for Petunia were 1.7, 1.9 and $2.1 \mathrm{dS} \mathrm{m}^{-1}$ for $68: 20: 12,86: 10: 04$ and 100:00:00, respectively, being significant the differences between the two most extreme treatments.

The treatment $\mathrm{x}$ date interaction was not significant $(0.063<p<0.873)$ in mineral nutrients concentrations and contents in leachate. Leachate's concentration of sulfate ions $\left(\mathrm{SO}_{4}^{-2}\right)$ did not differ significantly between treatments for either species ( $p \geq 0.884)$, but there was difference between species, resulting in a $27.6 \%$ higher for Pelargonium $401 \mathrm{mg} \mathrm{L}^{-1}$ than for Petunia $314 \mathrm{mg} \mathrm{L}^{-1}$. However, sampling date was significant $(p \leq 0.038)$ for sulfate ions, as concentration decreased from the first to the last date: 446 to $343 \mathrm{mg} \mathrm{L}^{-1}$ for Pelargonium and 363 to $240 \mathrm{mg} \mathrm{L}^{-1}$ for Petunia. Total sulfur's amount $(\mathrm{S}$, contained in sulfate ions, i.e. $\mathrm{S}_{-} \mathrm{SO}_{4}^{-2}$ ) per pot, as the sum of the five days sampled, averaged $35 \mathrm{mg}$ for Pelargonium and $38 \mathrm{mg}$ for Petunia.

Table 2 shows N, P and K leachates concentration values. $\mathrm{N}$ concentration in leachates was reduced in the mixed substrates compared to the control one in both species, while $\mathrm{K}$ concentration increased. In the case of $\mathrm{N}$, concentration decreased 18 to $22 \%$ in Petunia, and 17 to $40 \%$ in Pelargonium. Whereas for $\mathrm{K}$, the increments were $97 \%$ in Petunia, but only significant for the 68:20:12 treatment, and 29 to $53 \%$ in
Pelargonium. In Petunia phosphate-P form represented $46 \%$ of the total $\mathrm{P}$, whereas for Pelargonium it was 61\%. Regarding N, in Petunia, 89\% corresponded to nitrate-N, $10.9 \%$ to ammonium-N and the remaining $0.1 \%$ to nitrite-N. In Pelargonium, respective percentages were $97 \%, 2.9 \%$ and $0.1 \%$.

Figure 3 shows N, P and K total amount leached per pot during the five sampling days. The amount of nitrogen leached from the mixed substrates was reduced compared to the control one in both species (32 to $43 \%$ in Petunia and 26 to $47 \%$ in Pelargonium). These reductions were greater than the 14 and $32 \%$ reduction that could be attributed to the dilution of the control substrate in the mixtures $86: 10: 04$ and 68:20:12 respectively. In Petunia phosphorous decreased (30\%) for the 86:10:04 treatment, while potassium in 68:20:12 treatment increased by $100 \%$. Nutrients leached amount measurement related to the inorganic fertilizer added to the peat-based substrate and how much was a contribution of either $V$ or $B$ was not performed. In particular, $V$ contained a large amount of $\mathrm{N}, \mathrm{P}$ and $\mathrm{S}$, while $B$ of $\mathrm{K}, \mathrm{P}$ and $\mathrm{S}$. For instance, in the case of $\mathrm{N}$, the peat-based substrate together with the $5.9 \mathrm{~g} / \mathrm{L}$ of inorganic fertilizer added implied $892 \mathrm{mg} / \mathrm{L}$ of soluble $\mathrm{N}(1857 \mathrm{mg} / \mathrm{L}$ of total $\mathrm{N})$ in that substrate, while $V$ contained $408 \mathrm{mg} / \mathrm{L}$ of soluble $\mathrm{N}$, and $3799 \mathrm{mg} / \mathrm{L}$ of total $\mathrm{N}$. Therefore, $V$ contained less soluble $\mathrm{N}$

Table 2. Concentration, mean (SE), of N, P and $\mathrm{K}$ in the leachate collected from each pot for the different treatments and sampling dates. Huelva, ETSI, 2017.

\begin{tabular}{|c|c|c|c|c|c|c|}
\hline \multirow{2}{*}{$\begin{array}{l}\text { Treatment } \\
\left(\mathrm{mg} \mathrm{L}^{-1}\right)\end{array}$} & \multicolumn{3}{|c|}{ Petunia } & \multicolumn{3}{|c|}{ Pelargonium } \\
\hline & $\mathbf{N}$ & $\bar{P}$ & $\bar{K}$ & $\mathbf{N}$ & $\mathbf{P}$ & $\bar{K}$ \\
\hline 100:00:00 & $52.1(3.8) \mathrm{b}$ & $23.1(0.7) \mathrm{a}$ & $46.5(4.4) \mathrm{a}$ & $247(14) c$ & $18.2(1.3) \mathrm{a}$ & $208(22) a$ \\
\hline $86: 10: 04$ & $40.8(4.0) \mathrm{a}$ & $21.6(0.6) \mathrm{a}$ & $47.1(3.6) \mathrm{a}$ & $205(13) \mathrm{b}$ & $19.0(0.9) \mathrm{a}$ & 269 (21) ab \\
\hline $68: 20: 12$ & $42.9(2.5) \mathrm{b}$ & $24.4(0.9) \mathrm{a}$ & $91.6(5.6) b$ & $148(9) \mathrm{a}$ & $18.5(1.2) \mathrm{a}$ & $318(28) b$ \\
\hline$p$ & 0.031 & 0.052 & 0.034 & 0.016 & 0.958 & 0.034 \\
\hline \multicolumn{7}{|l|}{ Date } \\
\hline $1^{\text {st }}$ day & $55.7(5.5) c$ & $21.5(1.1) \mathrm{a}$ & $71.9(9.3) b$ & $246(28) b$ & $19.7(1.5) \mathrm{a}$ & $356(32) b$ \\
\hline $2^{\text {nd }}$ day & $53.1(3.8) \mathrm{bc}$ & $22.7(0.7) \mathrm{a}$ & $69.7(8.0) \mathrm{ab}$ & $230(21) a b$ & $19.3(1.4) \mathrm{a}$ & $290(21) b$ \\
\hline $3^{\text {rd }}$ day & $48.2(3.6) \mathrm{bc}$ & $23.1(1.2) \mathrm{a}$ & $66.5(9.8) \mathrm{ab}$ & $190(14) \mathrm{ab}$ & $20.1(1.7) \mathrm{a}$ & $229(27) b$ \\
\hline $4^{\text {th }}$ day & $39.6(4.0) \mathrm{ab}$ & $23.3(0.6) \mathrm{a}$ & $56.9(6.9) \mathrm{ab}$ & $180(11) \mathrm{a}$ & $18.1(1.1) \mathrm{a}$ & $203(22) a b$ \\
\hline $5^{\text {th }}$ day & $30.8(4.3) \mathrm{a}$ & $24.5(1.4) \mathrm{a}$ & $48.9(6.9) \mathrm{a}$ & $173(12) \mathrm{a}$ & $15.6(1.4) \mathrm{a}$ & $186(23) \mathrm{a}$ \\
\hline $\bar{p}$ & 0.006 & 0.131 & 0.039 & 0.013 & 0.056 & 0.003 \\
\hline
\end{tabular}

$p=$ significance level at 0.05 . Different letters in numerical columns differ at $p \leq 0.05$ (Tukey-HSD test). 
but more total $\mathrm{N}$ to be released slowly over time. Anyway, it is clear that there has been an interaction in the nutrient retention capacity between the different components of the substrate mixture, since: i) the amount of added inorganic fertilizer was reduced, regarding control treatment, $14 \%$ for $86: 10: 04$ and $32 \%$ for $68: 20: 12$; ii) water leached by alternative treatments, regarding control, presented, in general, a lower concentration of $\mathrm{N}$, greater than $\mathrm{K}$ and equal to $\mathrm{P}$ and $\mathrm{S}$; iii) in terms of total amount of nutrients leached (Figure 3) percentage reduction of $\mathrm{N}$ and $\mathrm{P}$ in the two alternative treatments was greater than the reduction of added fertilizer. In any case, as SDW and the number of flowers were not decreased, the overall response of the two mixtures containing $V$ and $B$ seems to be environmentally more attractive than peat based substrate to which soluble inorganic fertilizer need to be added, at least for nitrates and phosphates.

Taking into account the correlation analysis performed between leachate parameters, $\mathrm{pH}$ and $\mathrm{EC}$, it can be highlighted that: a) for both species, the total amount of nutrients in each leached sample (N, P, K, S) were positively correlated between themselves $(0.49<\mathrm{r}<0.89, p<0.001$, $48<\mathrm{n}<75$ ); b) for both species, $\mathrm{N}$ content and $\mathrm{N}$ concentration were negatively correlated with $\mathrm{pH}(-0.67<\mathrm{r}<-0.43$, $p<0.025, \mathrm{n}=30$ ); for Pelargonium, EC was positively correlated with $\mathrm{N}$, $\mathrm{K}$ and $\mathrm{S}$ concentrations and content $(0.44<\mathrm{r}<0.79, \mathrm{p}<0.023, \mathrm{n}=30)$.

Regarding leachates, the slight $\mathrm{pH}$ increase (an increment of only about $1.0)$ when $V$ and $B$ were added to the standard peat based growing media shows the capacity of $B$ and $V$ to serve as a liming agent when added to a peat-based substrate, in addition to their effects on the physical properties (Northup, 2013).

Referring to nutrient content in leachates, we observed that less quantity of $\mathrm{N}, \mathrm{K}$ and $\mathrm{S}$ has been leached in petunia compared to pelargonium. This fact also coincides with a remarkable greater production of flowers in the former species. In addition, the lower $\mathrm{N}$ and $\mathrm{S}$ concentrations in the leachates from Petunia (and therefore lower nitrate-N and sulfate-S) may be related to the higher $\mathrm{pH}$ compared to Pelargonium. Likewise, the higher N, K and $\mathrm{S}$ concentrations in the Pelargonium leachates compared to Petunia, may have influenced the positive relationship between these nutrients and EC in the former species.

The fact is that $\mathrm{N}$ concentration (Table 2) and $\mathrm{N}$ content (Figure 3) in leachates significantly decreased for both species as $V$ and $B$ increased, which could be due to nitrate retained to the biochar-vermicompost ensemble and more slowly released (Altland \& Locke, 2013; Kammann et al., 2014).

On the other hand, the increase of potassium concentration in leachates (and content for Petunia) as the ratio of biochar applied to the mixtures was also observed in Malińska et al. (2016), in which it was noted that biochar could be a significant source of $\mathrm{K}$ and should be accounted for in fertility programs (Altland \& Locke, 2013). It is not considered necessary to establish a health-based guideline value for potassium in drinking-water. Although potassium may cause some

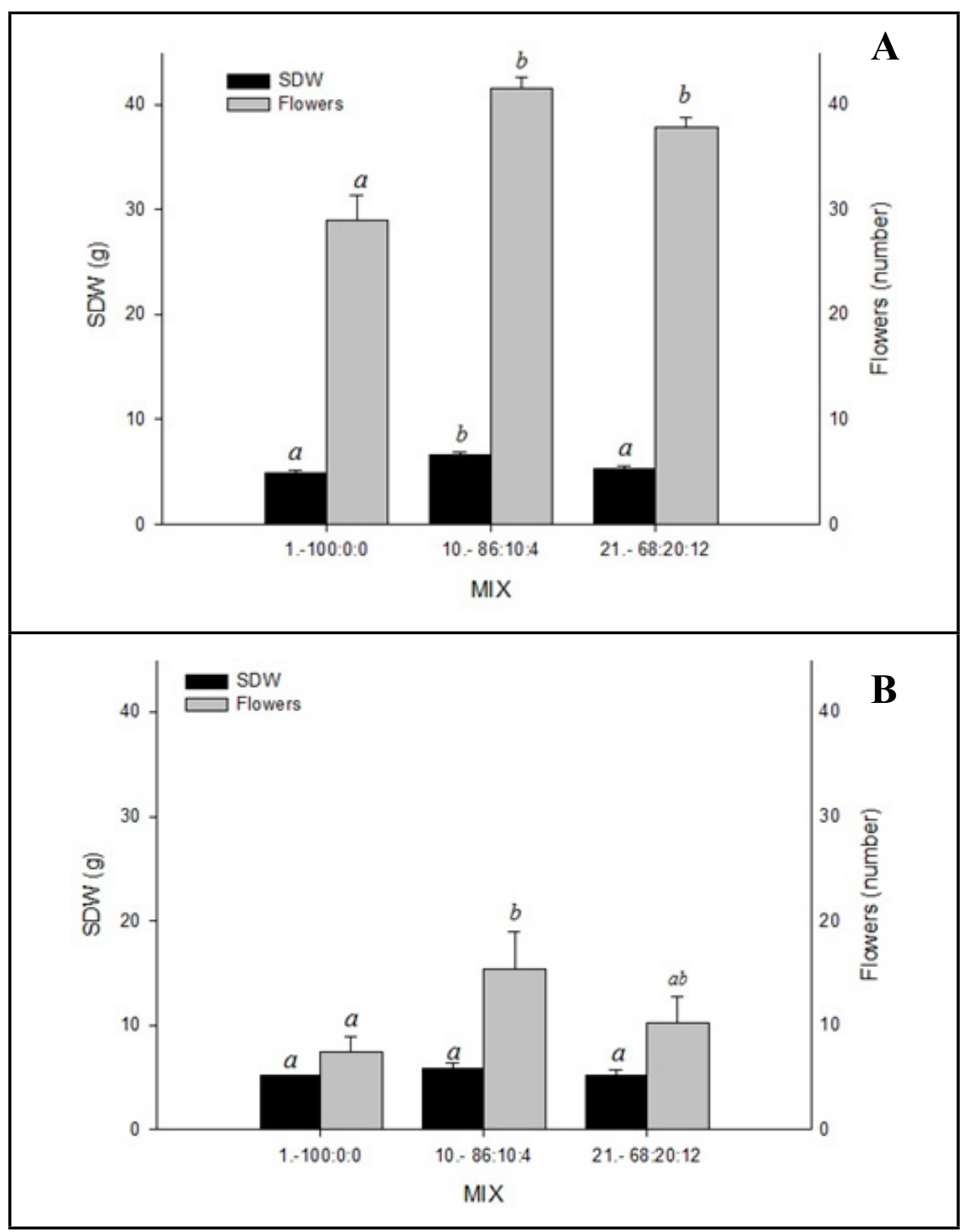

Figure 1. Shoot dry weight (SDW, g) and flower production number of petunia (A) and pelargonium (B) grown in mixtures with different proportions of peat-based substrate $(\mathrm{S})$, vermicompost $(\mathrm{V})$ and biochar $(\mathrm{B})(\mathrm{S}: \mathrm{V}: \mathrm{B})$. Letters show significant differences between substrates studied $(\mathrm{p}<0.05)$. (Tukey-HSD test for SDW both species, and for flowers in Petunia; T3-Dunnet test for flowers in Pelargonium). Columbus, OSU, 2016. 
health effects in susceptible individuals, potassium intake from drinking-water is well below the level at which adverse health effects may occur (WHO, 2009). Petunia's leachates, even if higher in volume, had less $\mathrm{N}$ and $\mathrm{K}$ concentration and content than Pelargonium's probably due a minor nutrients need of last species to grow and produce flowers (Karras et al., 2016). Therefore, the species grown in the pot can also affect the leachate mineral composition.

In this study we verified a partial reduction of nitrogen (mainly nitrate) in both species, and slightly $\mathrm{P}$ in Petunia, leached from the containers as consequence of the biocharvermicompost inclusion in the selected mixtures additional to the reduction due to the lower ratio of the control substrate in the mixtures. Also, biochar addition could be a significant source of potassium in growing media and may be considered in fertility programs. So, first section of our hypothesis was partially demonstrated.

Obtaining commercial quality plants with similar or even greater growth and

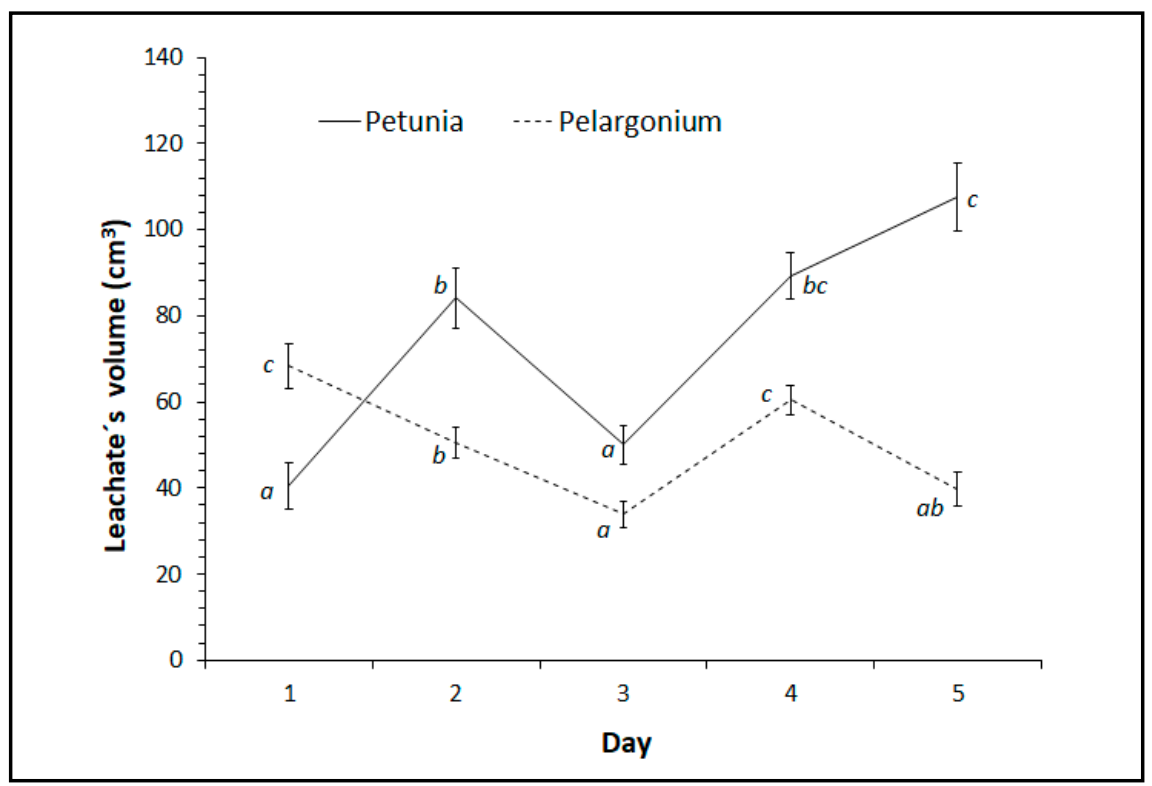

Figure 2. Leachate's volume $\left(\mathrm{cm}^{3}\right)$ of petunia and geranium grown in mixtures with different proportions of peat-based substrate $(\mathrm{S})$, vermicompost $(\mathrm{V})$ and biochar $(\mathrm{B}),(\mathrm{S}: \mathrm{V}: \mathrm{B})$. For each species letters show significant differences among sampling dates $(p<0.05)$. Huelva, ETSI, 2017. flowering than control substrate has served to evidence our second section of our hypothesis that renewable materials can be used for the production of these containerized ornamental plants.

Finally, as biochar produced from high temperature pyrolysis had more recalcitrant character for carbon sequestration and was able to store carbon in soil for longer periods of time (Jindo et al., 2014), so the third section of our hypothesis - climate change mitigation by reducing carbon foot print in this commercial sector - has also been positively addressed.

\section{ACKNOWLEDGEMENTS}

This work was partially supported by the project CTQ 2013-46804-C21-R, CTQ 2017-85251-C2-2-R and CGL2016-76498-R of the Spanish Ministry of Economy and Competitiveness and the European Regional Development Funds (ERDF).

The authors thank the Horticultural Department and Carbon Sequestration and Management Center of Ohio State University for providing materials and facilities for this investigation, also they are deeply grateful to the following people:

Mrs. Loewe and Dr. J. Altland from Application Technology Research Unit at Wooster OSU campus for their laboratory assistance in determining

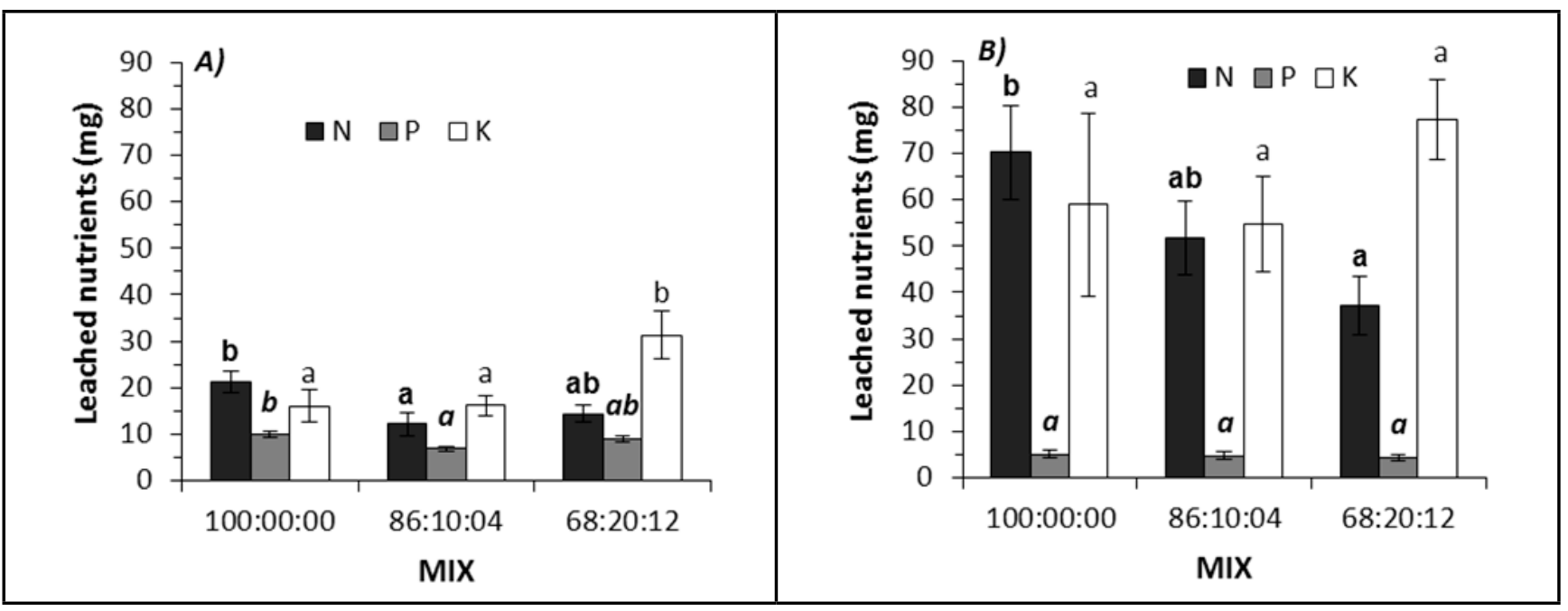

Figure 3. Total amount of nutrient leached by containers taken into account the five sample days. Letters show significant differences between substrates studied ( $<<0.05$ ), Tukey-HSD test. (A) Petunia, (B) Pelargonium. Huelva, ETSI, 2017. 
substrates mixtures physical properties. Dr. Manuel J. Díaz from Universidad de Huelva, Spain for his help reviewing the manuscript. The authors are grateful to the editors and two anonymous reviewers for investing substantial effort into helping to improve this work.

\section{REFERENCES}

AGEGNEHU, G; SRIVASTAVA, AK; BIRD, MI. 2017. The role of biochar and biocharcompost in improving soil quality and crop performance: A review. Applied Soil Ecology 119: 156-170.

AIPH, 2017. The international statistics flowers and plants yearbook. In: The international statistics flowers and plants yearbook. Hannover: Institut für Gartenbauökonomie.

ALTLAND, J; LOCKE, JC. 2013. Effect of biochar type on macronutrient retention and release from soilless substrate. HortScience 48:1397-1402. Retrieved from http://hortsci. ashspublications.org/content/48/11/1397. abstract

ALVAREZ, JM; PASIAN, C; LAL, R; LOPEZ, R; FERNANDEZ, M. 2017. Vermicompost and biochar as peat replacement for ornamental plant production. Journal of Applied Horticulture 19: 205-214. doi:10.17605/OSF. IO/PZBFS

ALVAREZ, JM; PASIAN, C; LAL, R; LOPEZ, R; FERNANDEZ, M. 2018. A biotic strategy to sequester carbon in the ornamental containerized bedding plant production. A review. Spanish Journal of Agricultural Research 16(3), e03R01. https:// doi.org/10.5424/sjar/2018163-12871

ANSORENA MINER, J. 1994. Sustratos propiedades y caracterización. Madrid: Mundi-Prensa. p141.

BARRETT, GE; ALEXANDER, PD; ROBINSON, JS; BRAGG, NC. 2016. Achieving environmentally sustainable growing media for soilless plant cultivation systems. A review. Scientia Horticulturae 212: 220-234. https://doi.org/10.1016/j. scienta.2016.09.030

BILDERBACK, TE; WARREN, SL; OWEN, JS; ALBANO, JP. 2005. Healthy substrates need physicals too. HortTechnology 15: 747-751.

CABRERA, R. 1997. Comparative evaluation of nitrogen release patterns from controlledrelease fertilizers by nitrogen leaching analysis. HortScience 32: 669-676.

DAHLQUIST, RL; KNOLL, JV. 1978. Inductively coupled plasma-atomic emission spectrometry: analysis of biological materials and soils for major trace, and ultra-trace elements. Applied Spectroscopy 32: 1-30.

DO, TCV; SCHERER, HW. 2013. Compost as growing media component for salt-sensitive plants. Plant and Soil Environment 59: 214220.

FONTENO, WC; BILDERBACK, TE. 1993. Impact of hydrogel on physical properties of coarse-structured horticultural substrates. Journal of the American Society for Horticultural Science 118: 217-222.

GRABER, ER; MELLER HAREL, Y; KOLTON, M; CYTRYN, E; SILBER, A; RAV DAVID, D; TSECHANSKY, L; BORENSHTEIN, M; ELAD, Y. 2010. Biochar impact on development and productivity of pepper and tomato grown in fertigated soilless media. Plant and Soil 337: 481-496. doi:10.1007/ s11104-010-0544-6

GUIMERÀ, J; MARFÀ, O; CANDELA, L; SERRANO, L. 1995. Nitrate leaching and strawberry production under drip irrigation management. Agriculture, Ecosystems \& Environment 56: 121-135. https://doi. org/10.1016/0167-8809(95)00620-6

JINDO, K; MIZUMOTO, H; SAWADA, Y; SANCHEZ-MONEDERO, MA; SONOKI, T. 2014. Physical and chemical characterization of biochars derived from different agricultural residues. Biogeosciences 11: 6613-6621. https://doi.org/10.5194/bg-11-6613-2014

KAMMANN, C; HAIDER, G; DEL CAMPO, B; MENGEL J; SCHMIDT, H.-P; MARHAN, SSTEFFENS D; CLOUGH, T. 2014. Nitrate retention by biochar: mechanistic insights by $15 \mathrm{~N}$ tracing. In ELS2014 -The Earth Living Skin: Soil, Life and Climate Changes. Italy: Bari. (ELS2014-152-1) 2-3. https://doi. org/10.13140/2.1.1540.6083

KARRAS, G; TSIROGIANNIS, IL; BAKEA, M; VARRAS, G; SAVVAS, D; LYKAS, C; SALAS, MC. 2016. A plants palette for hydroponic structures on buildings. Acta Horticulturae 1108: 279-286. DOI: 10.17660/ ActaHortic.2016.1108.36

KEDDY, PA. 2010. Wetland Ecology: Principles and Conservation ( $2^{\text {nd }}$ Edition), Cambridge: University Press. 497p. ISBN 978-0-52151940, doi: 10.1017/CBO9780511778179

MAJSZTRIK, JC; RISTVEY, AG; LEA-COX, JD. 2011. Water and nutrient management in the production of container-grown ornamentals. In: Horticultural Reviews 38: 253-297. USA: John Wiley \& Sons, Inc. https://doi. org/10.1002/9780470872376.ch7

MALIŃSKA, K; ZABOCHNICKA-ŚWIATEK, M; CÁCERES, R; MARFÀ, O. 2016. The effect of precomposted sewage sludge mixture amended with biochar on the growth and reproduction of Eisenia fetida during laboratory vermicomposting. Ecological Engineering 90: 35-41. https://doi. org/10.1016/j.ecoleng.2016.01.042

MONK, RW; WIEBE, HH. 1961. Salt tolerance $\&$ protoplasmic salt hardiness of various woody \& herbaceous ornamental plants. Plant Physiology 36: 478-482.

MUELLER, DK; HAMILTON, PA; HELSE, DR; HITT, KJ; RUDDY, BC. 1995. Nutrients in ground water and surface water of the United States: An analysis of data through 1992. Water-Resources Investigations Report 95: 4031. USGS Report 95-4031.

MULCAHY, DN; MULCAHY, DL; DIETZ, D. 2013. Biochar soil amendment increases tomato seedling resistance to drought in sandy soils. Journal of Arid Environments 88: 222225. doi:10.1016/j.jaridenv.2012.07.012.

MUPONDI, LT; MNKENI, PNS ; MUCHAONYERWA, P. 2014. Vegetable growth medium components: effects of dairy manure-waste paper vermicomposts on physicochemical properties, nutrient uptake and growth of tomato seedlings. International Journal of Agricultural Research, Sustainability, and Food Sufficiency 2: 23-31.

NORTHUP, J. 2013. Biochar as a replacement for perlite in greenhouse soilless substrates. Ames: iowa State. 64p. (BsC thesis) Paper 13399. http://lib.dr.iastate.edu/etd/13399

RUTER, JM. 1993. Growth and landscape performance of three landscape plants produced in conventional and pot-in-pot production systems. Journal of Environmental Horticulture 11: 124-127.

TIAN, Y; SUN, X; LI, S; WANG, H; WANG, L; CAO, J; ZHANG, L. 2012. Biochar made from green waste as peat substitute in growth media for Calathea rotundifola cv. Fasciata. Scientia Horticulturae 143: 15-18. doi:10.1016/j. scienta.2012.05.018

US DEPARTMENT OF THE INTERIOR | U.S. Geological Survey. 2016. http://minerals.usgs. gov/minerals/pubs/commodity/peat/index. $\mathrm{html}$ Accessed November 21, 2017.

WORLD HEALTH ORGANIZATION. 2009. Potassium in drinking-water. Background document for development of WHO Guidelines for Drinking-water Quality, 2. http://www.who. int/water_sanitation_health/water-quality/ guidelines/chemicals/potassium-background. pdf Accessed August 18, 2018.

YEAGER, T; GILLIAM, C; BILDERBACK, TE; FARE, D; NIEMIERA, A; TILT, K. 1997. Best management practices guide for producing container-grown plants. Atlanta: Southern Nurserymen's Association. 69p. 